\author{
JANusz KunKowsKI ${ }^{*}$ \\ Uniwersytet Mikołaja Kopernika w Toruniu
}

\title{
ROZWÓJ PŁATNOŚCI ZBLIŻENIOWYCH W POLSCE I NA ŚWIECIE
}

Słowa kluczowe: NFC, płatności zbliżeniowe, płatności mobilne, RFID. Klasyfikacja JEL: J33, G19.

\begin{abstract}
Abstrakt: Celem pracy jest ocena czynników sprzyjających wprowadzaniu przez instytucje uczestniczące w obrocie bezgotówkowym płatności zbliżeniowych na rynek oraz barier rozwoju tej innowacji. W artykule przedstawiono kierunki rozwoju innowacyjnych metod płatności oraz oceniono szanse zaistnienia w świadomości klientów metod najbardziej popularnych. Opisano również sposób funkcjonowania płatności zbliżeniowych oferowanych przez największe organizacje płatnicze. Sukces na rynku płatności odniosą te podmioty, które będą potrafiły przekonać swoich klientów do aktywnego korzystania z technologii zbliżeniowej.
\end{abstract}

\section{THE DEVELOPMENT OF CONTACTLESS PAYMENT MARKET in Poland AND in The WORLD}

Keywords: contactless, mobile payment, NFC, RFID. JEL Classification: J33, G19.

\begin{abstract}
The aim of the article is to assess factors that stimulate cashless payment organizations to introduction of contactless payment onto market, as well as the barrier for the development of this innovation. The paper presents the development directions of innovative payment methods. The article describes the evolution and functioning of contactless technology offered by the major payment organizations.
\end{abstract}

Translated by Janusz Kunkowski

Data wpłynięcia: 5.12.2012; data zaakceptowania: 25.02.2013.

* Dane kontaktowe: janusz.kunkowski@umk.pl, Katedra Zarządzania Finansami, Wydział Nauk Ekonomicznych i Zarządzania, Uniwersytet Mikołaja Kopernika, ul. Gagarina 13a, 87-100 Toruń, tel. 566114634. 


\section{WSTĘP}

W ciągu ostatnich lat rynek płatności przeszedł gwałtowne zmiany. Nie objęły one wszystkich krajów, jednak szybki rozwój nowych technologii dotknął również rynku płatności, który przez wiele lat pozostawał oporny na jakiekolwiek nowinki. Płatności detaliczne są wciąż zdominowane przez gotówkę, ale znaczny wzrost wykorzystania Internetu oraz liczby telefonów komórkowych stwarza zupełnie nowe podejście do usług płatniczych. Wiele podmiotów uczestniczących w obsłudze gotówki dąży do redukcji kosztów działalności przez zachęcanie sprzedawców i konsumentów do stosowania instrumentów elektronicznych zamiast drogiego w zarządzaniu pieniądza gotówkowego. Główną barierą we wprowadzaniu nowych, elektronicznych instrumentów płatniczych zastępujących gotówkę, zwłaszcza przy transakcjach niskokwotowych, były dotychczas koszty obsługi, znaczące w stosunku do niewielkiej wartości pojedynczej transakcji. Kolejne bariery to: ograniczona akceptacja płatności niskokwotowych przez sprzedawców, długi czas trwania transakcji oraz uciążliwe dla klientów korzystanie z instrumentów elektronicznych. Innowacje technologiczne wkraczające w nasze życie dają możliwość powstania nowych metod płatności, modeli rozliczeniowych oraz rozwoju metod dotychczas stosowanych. Sukces danej innowacji płatniczej zależy od zrozumienia faktu, że technologia nie jest najważniejszym składnikiem w świecie płatności, istotne jest stworzenie odpowiedniego modelu biznesowego, który będzie w stanie efektywnie funkcjonować.

Celem pracy jest ocena czynników sprzyjających wprowadzaniu przez instytucje uczestniczące w obrocie bezgotówkowym płatności zbliżeniowych. W artykule poruszono problemy popularyzacji oraz bariery rozwoju płatności zbliżeniowych w Polsce i na świecie. Przedstawiono kierunki rozwoju innowacyjnych metod płatności oraz oceniono szanse zaistnienia w świadomości klientów metod najbardziej popularnych. W pracy opisano również sposób funkcjonowania płatności zbliżeniowych oferowanych przez największe organizacje płatnicze.

\section{PIERWSZE WDROŻENIA KART ZBLIŻENIOWYCH}

Głównym celem rozwoju płatności elektronicznych jest dążenie do zastępowania gotówki. Największy problem dla obrotu bezgotówkowego stanowią transakcje o niewielkiej wartości, gdyż czas płatności kartą jest długi, a opłata 
interchange wysoka. Możliwość ograniczenia obrotu gotówkowego dostrzeżono w zastosowaniu szybko rozwijającej się technologii RFID (Radio Frequency IDentification). Technologia RFID nie jest nowa, jej początki sięgają bowiem II wojny światowej (Hancke 2008). Umożliwia ona zdalny odczyt układów scalonych za pomocą fal radiowych. System składa się z tagów oraz czytnika. Do komunikacji nie jest wymagany bezpośredni kontakt między tagiem a czytnikiem, dzięki czemu czas płatności jest szybki, a dodatkowo konsument nie musi podawać karty sprzedawcy, wystarczy, że zbliży ją do czytnika na odpowiednią odległość (RFID Journal 2011).

Niezależenie od formy, jaką może przybrać nowy instrument zbliżeniowy, dostrzeżono, że jest on w stanie dostarczyć wiele korzyści zarówno sprzedawcom, jak i konsumentom. Ze względu na bardzo szybki czas działania karty zbliżeniowe zaczęto stosować w komunikacji miejskiej. Pierwszym dużym wdrożeniem kart zbliżeniowych było wprowadzenie w 1997 roku systemu Octopus w Hongkongu, obsługującego opłaty w komunikacji miejskiej. Natomiast pierwszą międzynarodową organizacją płatniczą, która zdecydowała się na wdrożenie technologii zbliżeniowej, był MasterCard. Pilotażowy program MasterCard PayPass bankowych kart płatniczych wyposażonych w technologię zbliżeniową został zrealizowany w grudniu 2002 roku w Stanach Zjednoczonych. Korzyści płynące z nowej metody zostały szybko zauważone, dzięki czemu w krótkim czasie nastąpiło rozpowszechnienie kart zbliżeniowych na głównych rynkach światowych (Polasik, Kunkowski 2009).

Rynek płatności zbliżeniowych w Europie rozwija się odmiennie od rynku w USA. W Europie następuje migracja z kart chipowych działających zgodnie ze standardem EMV, w Stanach Zjednoczonych zaś - bezpośrednie przejście z technologii paska magnetycznego do technologii kart zbliżeniowych. Należy tutaj podkreślić, że ewolucja elektronicznych instrumentów płatniczych nie eliminowała poprzednich; przykładowo poprzednia technologia (pasek magnetyczny) nie była usuwana z samych kart oraz z infrastruktury terminali POS, natomiast nowo wydawane karty zbliżeniowe są wyposażane jednocześnie w trzy technologie płatności - pasek magnetyczny, mikroprocesor do płatności stykowych oraz mikroprocesor do płatności zbliżeniowych. Na rynku w USA karty są wyposażone tylko w dwie technologie.

Radiowa technologia zbliżeniowa daje możliwość odejścia od tradycyjnej formy karty i umieszczenia karty płatniczej w dowolnym niewielkim przedmiocie. Karty mogą być umieszczane w alternatywnych urządzeniach, np. w breloczkach do kluczy, zegarkach, obudowie telefonu. Jest to możliwe, po- 
nieważ karty zbliżeniowe nie muszą być fizycznie wkładane ani przeciągane $\mathrm{w}$ terminalu. W przypadku alternatywnych form karty nie jest możliwe dokonywanie transakcji w technologii stykowej. Gracze rynkowi dostrzegli, że nowa atrakcyjna forma kart zbliżeniowych może stać się dodatkowym czynnikiem sprzyjającym ich popularyzacji, zwłaszcza wśród ludzi młodych, a w konsekwencji spowodować zastąpienie przez tego typu płatności pewną część obrotu gotówkowego (Polasik, Kunkowski 2011).

Płatności kartami zbliżeniowymi odnoszą największy sukces w miejscach, gdzie liczy się szybkość i konieczność obsługi dużej liczby klientów. Pozwalają one na skracanie kolejek w salach koncertowych, na stadionach, w kasach biletowych, dużych centrach handlowych, barach szybkiej obsługi i innych miejscach imprez masowych, w których dominuje obrót gotówkowy, a istnieje potrzeba szybkiej realizacji transakcji. Szczególnie duże możliwości zastosowania zbliżeniowych kart płatniczych, uzupełnionych o specjalne aplikacje biletowe, występują w transporcie publicznym.

\section{POROZUMIENIE W SPRAWIE STANDARDóW}

Na rynku płatności znalazło zastosowanie kilka standardów komunikacji zbliżeniowej oraz niezależnych technologii. Wiele z tych rozwiązań odgrywa jedynie lokalną rolę i jest wykorzystywanych w ograniczonym zakresie, np. tylko do komunikacji publicznej. Natomiast główny nurt rozwoju systemów płatności zbliżeniowych o charakterze uniwersalnym wyznaczają największe organizacje kartowe, tj. American Express, MasterCard i Visa, które rozpoczęły wdrażanie tej technologii na masową skalę w wydawanych przez siebie kartach. Dzięki porozumieniu oraz unifikacji standardów płatności zbliżeniowych organizacje te nie musiały walczyć ze sobą i tracić ogromnych pieniędzy na promocje własnych rozwiązań. Dodatkowo, decydując się na współpracę w zakresie technologii zbliżeniowej, mogły szybciej osiągnąć efekt skali i przyspieszyć rozwój tego młodego rynku. W 2005 roku MasterCard International i Visa International zawarły porozumienie w celu wspólnego stosowania protokołu komunikacji dla płatności zbliżeniowych opierających się na technologii RFID. Porozumienie to otworzyło rynek na jeden wspólny standard dla wszystkich podmiotów uczestniczących w obsłudze płatności zbliżeniowych. Wspólna specyfikacja protokołu została wcześniej przetestowana przez MasterCard w ramach licznych pilotaży. Protokół jest oparty na specyfikacji MasterCard PayPass ISO/IEC 14443 Implementation Specification. W 2007 roku MasterCard przekazał PayPass 
ISO/IEC 14443 Implementation Specification v1.1 organizacji EMVCo, zarządzającej standardem EMV i należącej łącznie do JCB, MasterCard Worldwide i Visa International (Polasik, Wisniewski, Lightfoot 2012). Mimo współpracy organizacje zdecydowały się na rozwój w różnych kierunkach. Różnica uwidacznia się w czasie trwania transakcji oraz sposobie jej realizacji. Zbliżeniowe karty Visa payWave działają w trybie offline, natomiast karty MasterCard PayPass w trybie online. Sytuacja ta sprawia, że dla transakcji powyżej limitu zbliżeniowego wynoszącego w Polsce 50 PLN karta z technologią MasterCard PayPass pozwoli nam dokonać transakcji zbliżeniowej, jednak z użyciem kodu PIN. Dzięki temu klient zawsze realizuje transakcję zbliżeniową bez względu na kwotę transakcji, co zwiększa jego zaufanie do technologii zbliżeniowej i usprawnia proces obsługi w sklepie. Zastosowanie nietypowej formy karty zbliżeniowej, np. breloka, powoduje, że nie może ona jednocześnie być wyposażona w tradycyjny pasek magnetyczny ani stykowy mikroprocesor EMV. Płatność w tym przypadku odbywa się z wykorzystaniem technologii przekazywania danych paska magnetycznego lub EMV contactless online. Wadą pracy w trybie online jest wydłużenie czasu trwania transakcji. Zgodnie z wymogami organizacji Visa transakcje zbliżeniowe odbywają się w trybie offline. Dzięki temu czas dokonania płatności jest krótszy niż w przypadku MasterCard PayPass, jednak nie ma możliwości przekroczenia limitu 50 PLN. W przypadku transakcji powyżej limitu uży tkownik musi dokonać płatności stykowej z użyciem kodu PIN. Praca w trybie offline uniemożliwia również wykorzystanie technologii zbliżeniowej w postaci różnego rodzaju gadżetów. Przedstawiciele Visa tłumaczą zastosowanie technologii zbliżeniowej w trybie offline chęcią osiągnięcia maksymalnego czasu transakcji oraz bezpieczeństwa (Polasik, Kunkowski 2011).

Konsumenci decydują się na korzystanie $\mathrm{z}$ tego instrumentu płatniczego, który jest wygodny i szybki, dlatego tak chętnie wybierają gotówkę. Z badania przeprowadzonego na rynku polskim (Polasik, Górka i in. 2012) wynika, że tradycyjne karty płatnicze wyposażone w pasek magnetyczny lub mikroprocesor EMV są wolniejsze od gotówki, średnia różnica czasu między kartami i gotówką wyniosła około 20 sekund. Akceptanci muszą ponosić dodatkowe koszty obsługi kart płatniczych, natomiast kolejka w sklepie, w związku z dłuższym czasem obsługi płatności, wydłuża się. Sugeruje to, że zarówno z punku widzenia akceptantów, jak i konsumentów korzystanie z kart jest nieefektywne kosztowo, jednak płatności zbliżeniowe dzięki innowacyjnej technologii znacząco redukują czas dokonania płatności. Po raz pierwszy w historii instrument elek- 
troniczny jest na tyle efektywny, wygodny i szybki, że jest w stanie skutecznie rywalizować z gotówką.

\section{ZASTOSOWANIE TECHNOLOGII NFC W PŁATNOŚCIACH MOBILNYCH}

Płatności mobilne są uważane za najbardziej rewolucyjne oraz przyszłościowe płatności detaliczne, jednak przez wiele lat ich stosowanie było na tyle uciążliwe i niewygodne, że nie były w stanie zdobyć zbyt dużej liczby odbiorców. Zbliżeniowe płatności mobilne należą do najczęściej dyskutowanych rewolucji płatniczych. Naturalnym rozwojem płatności zbliżeniowych staje się przejście z płatności kartami zbliżeniowymi do płatności za pomocą telefonu komórkowego z wykorzystaniem tej samej infrastruktury akceptacji. Rozwój technologii bliskiego zasięgu NFC (Near Field Communication) sprawia, że płatność telefonem komórkowym staje się niezwykle łatwa i wygodna. W tej technologii tradycyjna forma karty płatniczej staje się niepotrzebna, a jednocześnie otwierają się szerokie możliwości integracji systemu płatności z innymi usługami i funkcjonalnościami dostępnymi w telefonie komórkowym. Firmy tworzące infrastrukturę do płatności zbliżeniowych dążą do osiągnięcia efektu synergii, który występuje między kartami zbliżeniowymi i płatnościami mobilnymi NFC. Ich celem jest wykorzystanie tej samej infrastruktury terminali płatniczych. W związku z tym większość instytucji przyjęła dwuetapową strategię rozwoju technologii zbliżeniowej. W pierwszym etapie zazwyczaj wdrażane są karty zbliżeniowe, a w drugim planowane są systemy płatności mobilnej oparte na technologii NFC. Początkowy rozwój płatności mobilnych z wykorzystaniem technologii NFC nie mógł przebiegać zbyt szybko ze względu na małą liczbę telefonów komórkowych z funkcją NFC, która jednak w ostatnim czasie bardzo wzrosła.

\section{RYNEK PŁATNOŚCI ZBLIŹENIOWYCH NA ŚWIECIE}

W 2011 roku liczba wszystkich kart płatniczych w Unii Europejskiej wyniosła $727 \mathrm{mln}$ (podobnie jak w 2010 roku) i nieznacznie wzrosła w porównaniu do 2009 roku (725,2 mln kart płatniczych). Stanowiło to około 1,44 karty płatniczej przypadającej na mieszkańca UE. Liczba transakcji kartami płatniczymi wzrosła o 8,7\% do 37,2 mld, natomiast wartość obrotów wyniosła 1,9 biliona euro. Pozwala to oszacować średnią wartość pojedynczej transakcji na 52 euro (Europejski Bank Centralny 2012). 
W tabeli 1 przedstawiono dane dotyczące liczby zbliżeniowych kart płatniczych na świecie. Karty organizacji American Express, MasterCard oraz Visa funkcjonują w oparciu o ten sam standard i w większości krajów są ze sobą kompatybilne. Nieco inaczej wygląda sytuacja w przypadku kart zbliżeniowych działających w technologii FeliCa (Felicity Card). Technologia ta jest wykorzystywana głównie w krajach azjatyckich, została stworzona przez firmę SONY. Po raz pierwszy zastosowano ją w 1997 roku w kartach Octopus w Hongkongu. FeliCa jest wykorzystywana przede wszystkim w transporcie publicznym i w systemach płatności, niestety w większości systemy stosujące technologię FeliCa nie są ze sobą kompatybilne (Crotch-Harvey 2010).

Tabela 1. Zbliżeniowe karty płatnicze na świecie (dane w milionach, stan na koniec 2009 roku)

\begin{tabular}{|c|c|c|c|c|c|}
\hline Kraj & $\begin{array}{c}\text { American } \\
\text { Express }\end{array}$ & MasterCard & Visa & FeliCa & Razem \\
\hline USA & 10 & 63 & 17 & - & 90 \\
\hline Wielka Brytania & - & 2,5 & 7 & - & 9,5 \\
\hline Japonia & - & - & - & 100 & 100 \\
\hline Korea Południowa & - & 0,3 & 0,5 & - & 0,8 \\
\hline Tajwan & - & 3 & 1,4 & - & 4,4 \\
\hline Malezja & - & 0,1 & 0,5 & - & 0,6 \\
\hline Turcja & - & 0,8 & - & - & 0,8 \\
\hline Polska & - & 0,2 & 0,12 & - & 0,32 \\
\hline Hongkong & - & - & - & 20 & 20 \\
\hline Razem & 10 & 69,9 & 26,5 & 120 & 226,4 \\
\hline
\end{tabular}

Źr ó d ł o : opracowanie własne na podstawie Crotch-Harvey 2010.

Pod względem liczby wyemitowanych zbliżeniowych kart płatniczych światowym liderem jest Japonia, w której znajduje się około 100 mln kart zbliżeniowych działających w technologii FeliCa. Tuż za Japonią znalazły się Stany Zjednoczone, gdzie zdecydowana większość kart funkcjonuje w standardzie ISO 14443 A/B. Warto zwrócić uwagę, że większość kart zbliżeniowych MasterCard PayPass została wydana na rynku amerykańskim. W Europie pierwsze 
karty MasterCard PayPass pojawiły się dopiero w połowie 2006 roku w Wielkiej Brytanii - zostały wydane przez Royal Bank of Scotland.

Należy podkreślić, że rynek płatności zbliżeniowych zmienia się bardzo dynamicznie, a doniesienia organizacji kartowych o rozpoczęciu współpracy z nowymi wydawcami kart sprawiają, iż liczba kart zbliżeniowych na świecie rośnie z roku na rok w bardzo szybkim tempie.

Tabela 2. Liczba zbliżeniowych terminali płatniczych na świecie (dane w tysiącach, stan na koniec 2009 roku)

\begin{tabular}{|c|c|c|}
\hline Kraj & American Express, MasterCard, Visa & Felica \\
\hline USA & 500 & - \\
\hline Wielka Brytania & 20 & - \\
\hline Turcja & 12 & - \\
\hline Japonia & - & 405 \\
\hline Korea Południowa & 5 & - \\
\hline Tajwan & 11 & - \\
\hline Malezja & 6 & - \\
\hline Singapur & 1,1 & - \\
\hline Francja & 1 & - \\
\hline Austria & 2,5 & - \\
\hline Polska & 10 & - \\
\hline Hongkong & - & 20 \\
\hline Razem & 568,6 & 425 \\
\hline
\end{tabular}

Źr ó d ło : opracowanie własne na podstawie Crotch-Harvey 2010.

Jeżeli chodzi o zasięg akceptacji, czyli liczbę zbliżeniowych terminali płatniczych w punktach handlowych, to niewątpliwymi liderami są Stany Zjednoczone i Japonia. Co ciekawe, rynek amerykański stanowi niejako jedną całość i karty trzech głównych organizacji są akceptowane we wszystkich terminalach. Natomiast na rynku japońskim działa kilka niekompatybilnych systemów płatności zbliżeniowych. Powoduje to, że realny zasięg płatności jest tam niższy, niż wynikałoby to z ogólnej liczby terminali. W pozostałych krajach świata sieć akceptacji kart zbliżeniowych jest wciąż niewielka, jednak należy pamiętać, że organizacjom płatniczym zależy na szybkim rozwoju sieci akceptacji. Je- 
śli infrastruktura terminali zbliżeniowych będzie dobrze rozwinięta, wówczas rynek stanie się bardzo interesujący dla rozwoju płatności mobilnych w technologii NFC.

\section{PŁatności mobilne W Polsce}

Pierwszej w Polsce transakcji zbliżeniowej Visa payWave telefonem komórkowym dokonano w czerwcu 2009 roku. Była to płatność zrealizowana telefonem z zainstalowaną na karcie aplikacją Visa payWave, który normalnie był wykorzystywany w Londynie (Visa 2010).

W kwietniu 2010 roku organizacja VISA, Bank Zachodni WBK oraz operator telefonii komórkowej Plus rozpoczęły pilotażowe wdrożenie płatności mobilnych z zastosowaniem technologii NFC. Aplikacja płatnicza Visa payWave została umieszczona bezpośrednio na karcie SIM abonentów sieci Plus, którzy za pomocą telefonu Samsung Avila wyposażonego w technologię NFC mogli dokonywać płatności zbliżeniowych w punktach, gdzie są akceptowane karty Visa payWave. W początkowym etapie wdrożenia wzięło udział 500 wybranych klientów Banku Zachodniego WBK korzystających z sieci Plus i używających kart zbliżeniowych Visa payWave wydanych przez BZ WBK. Co ciekawe, we wspólnym wdrożeniu płatności zbliżeniowych zostało wykorzystane rozwiązanie OTA (over the air), czyli zarządzanie kartą SIM na odległość, które pozwala na zdalną zmianę parametrów aplikacji płatniczej Visa payWave na karcie SIM. Oznacza to dość sporą wygodę dla klienta, gdyż nie musi on stawiać się w oddziale banku lub w salonie operatora sieci komórkowej w celu uruchomienia aplikacji płatniczej (Visa 2010).

W maju 2010 roku Polska Telefonia Cyfrowa (PTC) przy współpracy z Inteligo, PKO BP i MasterCard rozpoczęła pilotaż płatności zbliżeniowych NFC. Program trwał 4 miesiące i objął 100 uczestników, którzy otrzymali telefony Samsung Avila GT S5230N wyposażony w technologię NFC. Na potrzeby testu firma Giesecke \& Devrient przygotowała specjalne karty SIM, działające w zgodności z technologią NFC, przystosowane do współpracy ze wszystkim terminalami MasterCard PayPass. Dzięki temu osoby biorące udział w pilotażu mogły dokonywać transakcji zbliżeniowych wszędzie tam, gdzie były obsługiwane karty PayPass. Podobnie jak przy kartach zbliżeniowych PayPass, transakcje do 50 PLN były obsługiwane bez wprowadzania kodu PIN, natomiast większe transakcje wymagały podania kodu PIN (Inteligo 2010). 
Od 2010 roku technologia NFC była pilotażowo wdrażana przez wiele banków i instytucji finansowych w powiązaniu z operatorami telefonii komórkowych, jednak jak dotychczas trudno mówić o powszechnym użytkowaniu NFC. Na przestrzeni ostatnich kilku lat najwięksi światowi producenci telefonów komórkowych zaczęli wyposażać swoje najpopularniejsze modele w moduł NFC. Dzięki rosnącej liczbie telefonów komórkowych popularyzacja płatności mobilnych staje się coraz bardziej możliwa.

W listopadzie 2012 roku ruszyła usługa komercyjna o nazwie Orange Cash, w którą zaangażowały się operator telefonii komórkowej Orange, organizacja MasterCard oraz mBank. Usługa jest skierowana do klientów sieci Orange, którzy posiadają telefon z modułem NFC. Stanowi ona połączenie karty SIM Orange oraz karty przedpłaconej mBanku, dzięki której można płacić zbliżeniowo za pomocą telefonu komórkowego. Klient korzystający z tej usługi może dokonywać płatności zbliżeniowych w terminalach płatniczych PayPass oraz płatności zdalnych MasterCard Mobile, istnieje również możliwość wykorzystania karty mBank MasterCard Orange Cash do płatności w Internecie. Klient otrzymuje kartę SIM mBank MasterCard Orange Cash wraz z numerem rachunku. Usługa Orange Cash działa podobnie jak karta przedpłacona, czyli jest anonimowa, a w celu skorzystania z karty użytkownik musi ją wcześniej zasilić (Orange 2012).

Warto podkreślić, że korzystanie z telefonu komórkowego daje nam znacznie więcej możliwości oraz większe poczucie bezpieczeństwa niż w przypadku korzystania z karty zbliżeniowej. Pozwala użytkownikowi na zdefiniowanie różnych trybów działania aplikacji. Płatność zbliżeniowa za pomocą karty Visa payWave może odbyć się tylko do kwoty 50 PLN, powyżej tej kwoty transakcje są dokonywane w sposób standardowy. Natomiast przy płatności za pomocą telefonu komórkowego z systemem Visa payWave użytkownik ma możliwość przekroczenia limitu 50 PLN, wówczas transakcja zbliżeniowa musi być potwierdzona kodem PIN, który jest wpisywany za pomocą klawiatury telefonu komórkowego.

\section{ZAKOŃCZENIE}

Na rynku płatności zbliżeniowych obserwujemy gwałtownie zachodzące zmiany. Wydaje się, że głównym czynnikiem, który ukształtuje przyszły rozwój rynku płatności zbliżeniowych, jest efekt synergii, występujący między kartami zbliżeniowymi i płatnościami mobilnymi NFC. Wynika on z możliwości 
wykorzystania tej samej infrastruktury terminali płatniczych, gdyż obie technologie są do siebie bardzo podobne. Wczesne zaangażowanie wydawców i agentów rozliczeniowych w rozwój infrastruktury oraz technologii zbliżeniowej pozwala na zajęcie silnej pozycji tych podmiotów na rynku kart zbliżeniowych i płatności mobilnych. Wydaje się, że rozwój płatności mobilnych nie będzie oznaczać wycofania z rynku kart zbliżeniowych. Przyzwyczajenia klientów i powszechność akceptacji stykowych technologii płatniczych sprawiają, że karty zbliżeniowe będą bardzo długo funkcjonowały na rynku równolegle z technologią NFC. W związku z tym należy sądzić, że sukces odniosą te podmioty, które będą potrafiły przekonać swoich klientów do aktywnego korzystania z technologii zbliżeniowej. W Polsce obserwujemy niezwykle dynamiczny rozwój rynku płatności zbliżeniowych. Jest to niewątpliwie zasługa nowej jakości, którą wnoszą one na rynek, ponadto pozwalają odnieść korzyści wszystkim uczestnikom rynku. Szybki czas realizacji transakcji, wysoka wydajność oraz chęć korzystania przez nowe grupy społeczne sprawiają, że dynamicznie rośnie sieć akceptacji i wydawców. Barierą rozwoju rynku płatności elektronicznych może być silne przekonanie akceptantów, że gotówka jest najtańszą i najszybszą metodą płatności. Dopóki banki i organizacje płatnicze nie zmienią wysokości i struktury opłat, sprzedawcy będą odmawiać akceptacji elektronicznych instrumentów płatniczych w transakcjach o niskiej wartości. Dlatego sukces polskiego systemu płatności zależy w dużej mierze od stworzenia skutecznego modelu rozliczeniowego do obsługi mikropłatności, który zmierzałby do redukcji opłaty interchange.

Należy również zauważyć, że rynek płatności mobilnych jest na tyle interesujący, iż podmioty, które wcześniej nie uczestniczyły w obsłudze płatności, zaczynają się w nim pojawiać. Światowi giganci z różnych branż chcą brać udział w budowie tego nowego, perspektywicznego rynku. Takie firmy, jak Apple, Nokia czy Samsung, wyposażają swoje telefony w moduły NFC, natomiast Google przy współpracy z Citigroup i Visa rozwija usługę Google Wallet, która pozwala płacić telefonem komórkowym z systemem operacyjnym Android. Rynek płatności mobilnych może być następną wielką falą w biznesie technologicznym.

\section{UII LITERATURA}

Crotch-Harvey T. (2010), Contactless Cards and Terminals by Country and Scheme as at end 2009, Fenbrook Consulting, raport.

Europejski Bank Centralny (2012), Press and Information Division, http://www.ecb.int/ press/pr/date/2012/html/pr120910.en.html (dostęp: 13.11.2012). 
Hancke G. (2008), RFID and Contactless Technology, [w:] Smart Cards, Tokens, and Security Applications, K. E. Mayes, K. Markantonakis (red.), Springer, New York, http:// dx.doi.org/10.1007/978-0-387-72198-9_13.

Inteligo (2010), Era, Inteligo i MasterCard: pierwsza w Polsce komórka, która zapłacisz, http://inteligo.pl/aktualnosci/era-inteligo-i-mastercard-pierwsza-w-polscekomorka-ktora-zaplacisz (dostęp: 10.11.2012).

Orange (2012), Orange Cash, http://www.orange.pl/kid,4000377334,id,4002836765,title,Orange-Cash,article.html (dostęp: 18.11.2012).

Polasik M., Górka J., Wilczewski G., Kunkowski J., Przenajkowska K., Tetkowska N. (2012), Chronometric analysis of a payment process for cash, cards and mobile devices, Proceedings of the $14^{\text {th }}$ International Conference on Enterprise Information Systems, vol. 2, SciTePress, Wrocław.

Polasik M., Kunkowski J. (2009), Zastosowania technologii RFID w systemach płatności, [w:] E-gospodarka-e-społeczeństwo w Europie Środkowej i Wschodniej, t. 2, S. Partycki (red.), Wydawnictwo KUL, Lublin 2009.

Polasik M., Kunkowski J. (2011), Application of Contactless Technology in the Payment Cards Market, Prace Naukowe Uniwersytetu Ekonomicznego we Wrocławiu, nr 205, [w:] Advanced Information Technologies for Management - AITM'2011, J. Korczak, H. Dudycz, M. Dyczkowski (red.), Wrocław 2011.

Polasik M., Wisniewski T. P., Lightfoot T. P. (2012), Modeling Customers' Intentions to Use Contactless Cards, International Journal of Banking, Accounting and Finance, vol. 4, no. 3.

RFID Journal (2011), The History of RFID Technology, http://www.rfidjournal.com (dostęp: 2.11.2012).

Visa (2010), Visa Mobile: pierwsze w Polsce wdrożenie mobilnych płatności zbliżeniowych, http://www.visa.pl/visa_w_polsce/aktualnosci/aktualnosci/articles/2010/visa_ mobile_pierwsze_w_polsce.aspx (dostęp: 30.10.2012). 